\title{
Family association study between DRD2 and DRD3 gene polymorphisms and schizophrenia in a Portuguese population
}

\author{
Alda M. Ambrósio ${ }^{\mathrm{a}, *}$, James L. Kennedy ${ }^{\mathrm{b}}$, Fabio Macciardi ${ }^{\mathrm{b}}$, António Macedo ${ }^{\mathrm{c}}$, \\ José Valente ${ }^{c}$, Ana Dourado ${ }^{c}$, Catarina R. Oliveira ${ }^{a}$, Carlos Pato ${ }^{\mathrm{d}}$ \\ ${ }^{a}$ Department of Neurochemistry, Faculty of Medicine, Center for Neuroscience of Coimbra, University of Coimbra, \\ 3004-517 Coimbra, Portugal \\ ${ }^{\mathrm{b}}$ Neurogenetics Section, Center for Addiction and Mental Health, University of Toronto, Toronto, ON, Canada \\ ${ }^{\mathrm{C} D e p a r t m e n t}$ of Psychological Medicine, Faculty of Medicine, University of Coimbra, Coimbra, Portugal \\ ${ }^{\mathrm{d}}$ Center for Psychiatric and Molecular Genetics, SUNY Upstate Medical University and Behavioral Health Care Line, VISN 2, \\ Veterans Administration, Syracuse, NY, USA
}

Received 27 February 2003; received in revised form 23 September 2003; accepted 22 December 2003

\begin{abstract}
Schizophrenia is a highly heritable condition, as demonstrated in family, twin and adoption studies. Candidate genes from the dopaminergic system have long been hypothesized to be involved in the etiology of this disorder. In the present study, we investigated the genetic association between polymorphisms in the D2 and D3 dopamine receptor (DRD2, DRD3) genes and schizophrenia. We examined 90 trios from Portugal, and negative results were obtained from association studies with both Haplotype Relative Risk (HRR) and Transmission Disequilibrium Test (TDT), as well as TRANSMIT. Therefore, we conclude that neither the DRD2 nor the DRD3 gene polymorphisms investigated are associated with schizophrenia in our sample.
\end{abstract}

(c) 2004 Elsevier Ireland Ltd. All rights reserved.

Keywords: Schizophrenia; Association study; Candidate genes; Linkage disequilibrium; Haplotypes

\section{Introduction}

Schizophrenia is a complex genetic disorder that affects approximately $1 \%$ of the worldwide population. Despite extensive research efforts for many years, no mutations or disease-predisposing DNA sequence variations have been identified. The mode of inheritance of schizophrenia is likely to be polygenic/multifactorial (McGuffin et al.,

\footnotetext{
*Corresponding author. Tel.: +351-239-820190; fax: + 351-239-822776.

E-mail address: aldachico@yahoo.com (A.M. Ambrósio).
}

1995), and association studies are the most important strategies to investigate the candidate genes implicated in this disorder.

Although the biological basis of schizophrenia is unknown, dopamine is considered to be the main neurotransmitter implicated in this disease, and genes involved in dopaminergic pathways are being studied as candidate genes for schizophrenia. Five distinct subtypes of G-protein-coupled dopamine receptors mediate the actions of dopamine, three of which belong to the dopamine D2 family: the dopamine D2 receptor (DRD2), the dopamine 
D3 receptor (DRD3) and the dopamine D4 receptor (DRD4) (for review, see Missale et al., 1998). The DRD2 is expressed in both limbic and caudate areas and is a target of all antipsychotic drugs. These characteristics make the DRD2 gene an interesting candidate for schizophrenia. The human DRD2 and DRD3 genes were cloned and are localized to chromosome 11q22-q23 (Grandy et al., 1989) and chromosome 3q13.3 (Le Coniat et al., 1991), respectively. The DRD3 gene is structurally related to the DRD2 gene and was suggested to be a favored candidate gene for schizophrenia because it is selectively expressed in the limbic areas, which are associated with cognitive, emotional, and endocrine functions (Sokoloff et al., 1990). The TaqI-A and Ser311Cys polymorphisms located in the $3^{\prime}$ flanking region and in the coding region of the DRD2 gene, respectively, and the Ser9Gly polymorphism located in the coding region of DRD3 may be directly or indirectly implicated in schizophrenia through dopaminergic or other systems (Carlsson et al., 2001). Genetic variation in these genes might account for interindividual differences in response to drugs. Moreover, alterations in genes coding for receptor proteins as, for example, DRD2 and DRD3, may affect their binding affinities for neuroleptics, the efficiency of signal transduction, or their levels of expression, which may in turn alter the drug's therapeutic action.

Several case-control studies have investigated the possible involvement of the DRD2 and DRD3 genes in schizophrenia, but the results are inconclusive (Dubertret et al., 1998; Spurlock et al., 1998; Williams et al., 1998; Kremer et al., 2000; Hori et al., 2001; Himei et al., 2002; Morimoto et al., 2002). However, meta-analyses have recently supported the involvement of the DRD2 and DRD3 genes in the pathogenesis of schizophrenia (Jönsson et al., 2003a,b). Thus, more independent family association studies are required, mainly using a homogeneous population as, for example, the Portuguese population (Schindler et al., 1999). In the present study, we investigated the possible involvement of polymorphisms of the DRD2 and DRD3 genes in schizophrenia by using family association studies in a Portuguese population.

\section{Methods}

\subsection{Subjects}

The sample used in this study consisted of 90 unrelated schizophrenic patients from Azores and Mainland, Portugal (58 males and 32 females) and their parents, for a total of 270 individuals. All of the subjects were Caucasian and ethnically Portuguese. Approval was obtained from local ethics committees, and informed consent was given by all subjects. All patients were administered the Diagnostic Interview for Genetics Studies (DIGS), rated with the Operational Criteria checklist (OPCRIT), and all were diagnosed according to DSM-IV. Blood samples were collected with EDTA as anticoagulant, and genomic DNA was prepared using the standard method (Miller et al., 1988).

\subsection{Laboratory methods}

\subsubsection{DRD2 gene polymorphisms}

The amplification of the TaqI-A polymorphism of the DRD2 gene was carried out according to the method described by Grandy et al. (1993), with some modifications. A total of $100 \mathrm{ng}$ genomic DNA was amplified by polymerase chain reaction (PCR) in a volume of $25 \mu \mathrm{l}$ containing 200 $\mu \mathrm{M}$ dNTPs, $1 \mu \mathrm{M}$ of each primer, $1 \times$ reaction buffer, $1.5 \mathrm{mM} \mathrm{MgCl} 2$, and 1 unit of Taq polymerase. After initial denaturation at $94{ }^{\circ} \mathrm{C}$ for 5 min, 30 cycles of PCR reaction were performed under the following conditions: denaturation at 94 ${ }^{\circ} \mathrm{C}, 1 \mathrm{~min}$, annealing at $56{ }^{\circ} \mathrm{C}, 1 \mathrm{~min}$, and extension at $72{ }^{\circ} \mathrm{C}, 1 \mathrm{~min}$. Amplification products were digested with TaqI restriction enzyme at $65{ }^{\circ} \mathrm{C}$, and separated by electrophoresis in a $2 \%$ Metaphor (FMC BioProducts, Portugal) agarose gel, and visualized with ethidium bromide staining under ultraviolet light.

The Ser311Cys polymorphism of the DRD2 gene was investigated by PCR, using the protocol described by Arinami et al. (1994), with some modifications. The amplification was performed in a final volume of $25 \mu \mathrm{l}$, containing $100 \mathrm{ng}$ genomic DNA as template, $200 \mu \mathrm{M}$ dNTPs, 0.2 pmol of each primer, $10 \mathrm{mM}$ Tris- $\mathrm{HCl}(\mathrm{pH} \mathrm{8.3)}$, 
Table 1

HRR and TDT results for two individual TaqI-A and Ser311Cys polymorphisms of DRD2 gene in Portuguese schizophrenic trios

\begin{tabular}{lccc}
\hline & \multicolumn{2}{c}{ DRD2 gene } \\
\cline { 2 - 4 } & Transmitted & Not-transmitted & $\chi^{2}$ (d.f. $\left.=1\right), P$-value \\
\hline HRR & 79 & 76 & $\chi^{2}=0.045, P=0.831$ \\
TaqIA1 & 101 & 104 & $\chi^{2}=0.169, P=0.681$ \\
TaqIA2 & 4 & 2 & \\
Cys311 & 176 & 178 & \\
Ser311 & & & $\chi^{2}=0.064, P=0.800$ \\
TDT & 72 & 69 & $\chi^{2}=0.667, P=0.414$ \\
TaqIA1 & 69 & 72 & \\
TaqII2 & 4 & 2 & \\
Cys311 & 2 & 4 & \\
Ser311 & 2 & &
\end{tabular}

$2.0 \mathrm{mM} \mathrm{MgCl}_{2}$, and 1 unit of Taq polymerase. PCR amplification was initiated at $94{ }^{\circ} \mathrm{C}$ for 5 min and performed for 30 cycles each consisting of $94{ }^{\circ} \mathrm{C}$ for $30 \mathrm{~s}, 66{ }^{\circ} \mathrm{C}$ for $30 \mathrm{~s}$, and $72{ }^{\circ} \mathrm{C}$ for 30 s. PCR products were digested using enzyme Sau96I. The digested fragments were separated in $3.5 \%$ agarose gel and were visualized by ethidium bromide staining.

\subsubsection{DRD3 gene polymorphism}

The analysis of the Ser9Gly polymorphism of the DRD3 gene was carried out by using a PCRbased restriction analysis according to the method described by Lannfelt et al. (1992), with slight modifications. The PCR was carried out in a total volume of $25 \mu$ l containing 100 ng genomic DNA as template, $100 \mu \mathrm{M}$ dNTPs, 0.4 pmol of each primer, $10 \mathrm{mM}$ Tris- $\mathrm{HCl}(\mathrm{pH} 8.3), 1.5 \mathrm{mM}$ $\mathrm{MgCl}_{2}, 0.01 \%$ gelatine and 1.5 unit of Taq polymerase. After initial denaturation at $95{ }^{\circ} \mathrm{C}$ for 5 min, 35 cycles of PCR reaction were performed under conditions of denaturation at $95{ }^{\circ} \mathrm{C}$ for 30 $\mathrm{s}$, annealing at $56{ }^{\circ} \mathrm{C}$ for $30 \mathrm{~s}$, and extension at 72 ${ }^{\circ} \mathrm{C}$ for $30 \mathrm{~s}$. Amplification products were digested with MscI restriction enzyme, separated by electrophoresis in a $3.5 \%$ agarose gel, and visualized with ethidium bromide staining under ultraviolet light.

\subsection{Statistical analysis}

In this study, the association analysis was performed with 90 nuclear families with one proband (trios), and two strategies were used, the Haplotype Relative Risk (HRR) (Terwilliger and Ott, 1992), and Transmission Disequilibrium Test (TDT) (Spielman et al., 1993; Spielman and Ewens, 1998). We used the HRR and TDT to avoid any potential population stratification. In these methods, the non-transmitted parental alleles were used as 'controls' to evaluate allele transmission. The TDT-STDT program ( $\mathrm{v} 1.1)$ uses data from heterozygous parents only, and tests for individual markers. Furthermore, multiple marker haplotype transmission was performed with program TRANSMIT v2.5 (Clayton, 1999). The program TRANSMIT tests for association between markers and disease, examining the transmission of multilocus haplotypes.

\section{Results}

We investigated the relationship between some polymorphisms at DRD2 and DRD3 genes and schizophrenia. Genotypes were obtained from 90 Portuguese schizophrenic patients and their parents. In association analysis we used HRR and TDT methods to test if the marker locus and the hypothetical disease locus were linked or in linkage disequilibrium. Table 1 presents the results of HRR and TDT analysis for the individual markers (TaqI-A, Ser311Cys) at the DRD2 gene. When the HRR design was used, no significant differences were observed between transmitted and nontransmitted alleles for both polymorphisms of the 
DRD2 gene (TaqI-A polymorphism: $\chi^{2}=0.045$, d.f. $=1, P=0.831$; Ser311Cys polymorphism: $\chi^{2}=$ 0.169 , d.f. $=1, P=0.681$ ).

With TDT analysis no significant transmission disequilibrium between the alleles of the DRD2 gene and schizophrenia was found (TaqI-A polymorphism: $\quad \chi^{2}=0.064, \quad$ d.f. $=1, \quad P=0.800$; Ser311Cys polymorphism: $\chi^{2}=0.667 ; P=0.414$; see Table 1). The haplotypes of paired markers for transmission disequilibrium were analyzed by using TRANSMIT, and no evidence for linkage disequilibrium was observed (Table 2).

Relative to the DRD3 gene, using the HRR and the TDT designs, we found no evidence for association and linkage disequilibrium between the Ser9Gly polymorphism and schizophrenia (HRR: $\chi^{2}=0.117$, d.f. $=1, P=0.733$; TDT: $\chi^{2}=0.216$, d.f. $=1, P=0.642$; Table 3 ).

\section{Discussion}

In complex disorders like schizophrenia, various susceptibility genes are considered to be involved in etiology. Family-based association studies are an appropriate way to explore the putative contribution of candidate genes. Concerning molecular genetic studies, schizophrenia is one of the most extensively studied brain disorders, and attention has been given to the dopaminergic system, with special focus on the dopamine D2-like (DRD2, DRD3, DRD4) receptor subtype genes, with inconclusive results. Several factors could complicate the molecular genetics of schizophrenia, including genetic heterogeneity. To avoid genetic heterogeneity, it is crucial to study homogeneous populations such as, for example, the Portuguese population (Schindler et al., 1999). Therefore, in this study, we used this population to investigate
Table 3

HRR and TDT results for individual Ser9Gly polymorphism of the DRD3 gene in Portuguese schizophrenic trios

\begin{tabular}{crrr}
\hline & \multicolumn{3}{c}{ DRD3 gene } \\
\cline { 2 - 4 } & Transmitted & Not-transmitted & $\chi^{2}$ (d.f. $\left.=1\right), P$-value \\
\hline HRR & & & $\chi^{2}=0.117, P=0.733$ \\
Ser9 & 122 & 126 & \\
Gly9 & 58 & 54 & $\chi^{2}=0.216, P=0.642$ \\
TDT & & & \\
Ser9 & 35 & 39 & \\
Gly9 & 39 & 35 &
\end{tabular}

the involvement of polymorphisms at the DRD2 and DRD3 genes in schizophrenia by using association studies.

Using a dual genetic approach of association analysis, HRR and TDT, we found no evidence of association or linkage disequilibrium of the nonfunctional TaqI-A polymorphism and functional Ser311Cys polymorphism in the DRD2 gene and schizophrenia. Similarly, the analysis of the haplotypes did not show evidence of linkage disequilibrium between these polymorphisms and schizophrenia. Our findings for TaqI-A and Ser311Cys polymorphisms do not corroborate previous findings obtained with case-control association studies (Arinami et al., 1994, 1996) and meta-analysis (Jönsson et al., 2003a). However, they are in agreement with case-control association studies carried out in different populations (Itokawa et al., 1993; Sasaki et al., 1996; Tanaka et al., 1996; Spurlock et al., 1998; Hori et al., 2001; Himei et al., 2002). Other authors also have obtained inconsistent results with association studies with the $-141 \mathrm{C}$ Ins/Del polymorphism at the DRD2 gene (Li et al., 1998; Breen et al., 1999; Jönsson et al., 1999; Himei et al., 2002).

Table 2

Estimated haplotype probabilities and chi-square test of transmission of multi-marker haplotypes at the DRD2 gene using TRANSMIT

\begin{tabular}{lccccc}
\hline \multicolumn{7}{c}{ DRD2 gene } \\
\hline Haplotypes & Obs & Exp & O-E & Frequency & Haplotypic $P$-value \\
\hline TaqIA2/Cys311 & 4 & 3 & 1.5 & 0.017 & 0.414 \\
TaqIA1/Ser311 & 79 & 77.5 & 35.25 & 0.430 & 0.801 \\
TaqIA2/Ser311 & 97 & 99.5 & 34.75 & 0.179 & 0.672 \\
\hline
\end{tabular}


Taken together, the results of the analysis of individual alleles, as well as the analysis of haplotypes, appear to exclude a direct role of these polymorphisms at the DRD2 gene in the pathogenesis of schizophrenia in our sample. Because the Ser311Cys polymorphism, which is located in the coding region, might be of physiological and pathophysiological relevance to schizophrenia, further investigations with this polymorphism in other populations, as well as confirmatory studies in populations already investigated, are needed.

The DRD3 gene has been the most investigated gene for susceptibility to schizophrenia, and published data with case-control association studies have implicated the DRD3 gene as a risk factor for this disorder (Kennedy et al., 1995; Mant et al., 1994; Shaikh et al., 1996; Dubertret et al., 1998; Jönsson et al., 2003b). Our results, obtained with two powerful strategies of association (HRR and TDT), indicate that the Ser9Gly polymorphism in the first exon of the DRD3 gene is unlikely to be involved in schizophrenia in our sample. Our findings are in accordance with case-control association studies (Jönsson et al., 1993; Nimgaonkar et al., 1993; Yang et al., 1993; Di Bella et al., 1994; Chen et al., 1997), and with family-based association studies (Macciardi et al., 1994; Rothschild et al., 1996; Prasad et al., 1999; Kremer et al., 2000). Although negative, our results can only exclude a very large effect of the investigated polymorphism on schizophrenia in this population. In addition, there is the possibility that molecular defects in other genes that regulate the expression of the DRD3 gene could be involved in the pathogenesis of schizophrenia.

The DRD2 and DRD3 genes were screened for polymorphisms related to schizophrenia. When different methodologies of association were used, the results failed to demonstrate a minor effect of the TaqI-A, Ser311Cys and Ser9Gly polymorphisms in the predisposition to schizophrenia in our sample. As in other studies, our sample did not have enough power to detect an association due to a gene with a small effect, and further studies on a larger sample are required before excluding DRD2 and DRD3 genes in the etiology of schizophrenia in the Portuguese population. Despite these negative results, the dopamine sys- tem remains an important area of investigation in schizophrenia. However, the dopamine system alone is clearly insufficient to explain many biological factors underlying this disorder. Interactions between dopamine and other neurotransmitter systems in complex neurocircuits may play a crucial role in the pathogenesis of schizophrenia yielding a multifactorial view of this disease (Carlsson et al., 2001).

The strategy for future genetic studies on schizophrenia must use larger samples to increase statistical power. Furthermore, the development of more powerful statistical analyses applying a best definition of the clinical phenotype of the disease by using endophenotypes will also be very important to clarify the role of DRD2 and DRD3 genes in schizophrenia.

\section{Acknowledgments}

This work was supported by the Medical Research Council of Canada, the National Institute of Mental Health (USA) and Fundação para a Ciência e a Tecnologia, Portugal.

\section{References}

Arinami, T., Itokawa, M., Aoki, J., Shibuya, H., Ookubo, Y., Iwawaki, A., Ota, K., Shimizu, H., Hamaguchi, H., Toru, M., 1996. Further association study of the dopamine D2 receptor variant S311C in schizophrenia and affective disorders. American Journal of Medical Genetics 67, 133-138.

Arinami, T., Itokawa, M., Enguchi, H., Tagaya, H., Yano, S., Shimizu, H., Hamaguchi, H., Toru, M., 1994. Association of dopamine D2 receptor molecular variant with schizophrenia. Lancet 343, 703-704.

Breen, G., Brown, J., Maude, S., Fox, H., Collier, D., Li, T., Arranz, M., Shaw, D., Clair, D., 1999. -141C Del/Ins polymorphism of the dopamine receptor 2 gene is associated with schizophrenia in a British population. American Journal of Medical Genetics 88, 407-410.

Carlsson, A., Waters, N., Holm-Waters, S., Tedroff, J., Nilsson, M., Carlsson, M.L., 2001. Interactions between monoamines, glutamate, and GABA in schizophrenia: new evidence. Annual Review of Pharmacology and Toxicology 41, 237-260.

Chen, C.H., Liu, M.Y., Wei, F.C., Koong, F.J., Hwu, H.G., Hsiao, K.-J., 1997. Further evidence of no association between Ser 9 Gly polymorphism of dopamine D3 receptor gene and schizophrenia. American Journal of Medical Genetics 74, 40-43. 
Clayton, D., 1999. A generalization of the transmission/ disequilibrium test for uncertain-haplotype transmission. American Journal of Human Genetics 65, 1170-1170.

Di Bella, D., Catalano, M., Strukel, A., Nobile, E., Smeraldi, E., 1994. Distribution of the MscI polymorphism of the dopamine D3 receptor in an Italian psychotic population. Psychiatric Genetics 4, 39-42.

Dubertret, C., Gorwood, P., Ades, J., Feingold, J., Schwartz, J.-C., Sokoloff, P., 1998. Meta-analysis of DRD3 gene and schizophrenia: ethnic heterogeneity and significant association in Caucasians. American Journal of Medical Genetics 81, 318-322.

Grandy, D.K., Litt, M., Allen, L.J., Bunzow, J., Magenis, R.E., Civelli, O., 1989. Dopamine D2 receptor maps to human chromosome 11q22-q23 and identifies a TaqI RFLP. Cytogenetics and Cell Genetics 51, 1007.

Grandy, D.K., Zhang, Y., Civelli, O., 1993. PCR detection of the TaqA RFLP at the DRD2 locus. Human Molecular Genetics 2, 2197.

Himei, A., Koh, J., Sakai, J., Inada, Y., Akabame, K., Yoneda, H., 2002. The influence on the schizophrenic symptoms by the DRD2Ser/Cys311 and -141C Ins/Del polymorphisms. Psychiatry and Clinical Neuroscience 56, 97-102.

Hori, H., Ohmori, O., Shinkai, T., Kojima, H, Nakamura, J., 2001. Association between three functional polymorphisms of dopamine D2 receptor gene and tardive dyskinesia in schizophrenia. American Journal of Medical Genetics 105, 774-778.

Itokawa, M., Arinami, T., Futamura, N., Hamaguchi, H., Toru, M., 1993. A structural polymorphism of human dopamine D2 receptor D2 (Ser311Cys). Biochemical and Biophysical Research Communications 3, 1369-1375.

Jönsson, E.G., Lanfelt, L., Sokoloff, P., Schwartz, J.C., Sedvall, G., 1993. Lack of association between schizophrenia and alleles in the dopamine D3 receptor gene. Acta Psychiatrica Scandinavica 87, 345-349.

Jönsson, E.G., Nöthen, M.M., Neidt, H., Forslund, K., Rylander, G., Mattila-Evenden, M., Åsberg, M., Propping, P., Sedvall, G.C., 1999. Association between a promoter polymorphism in the dopamine D2 receptor gene and schizophrenia. Schizophrenia Research 40, 31-36.

Jönsson, E.G., Sillen, A., Vares, M., Ekholm, B., Terenius, L., Sedvall, G.C., 2003a. Dopamine D2 receptor gene Ser311Cys variant and schizophrenia: association study and meta-analysis. American Journal of Medical Genetics 119B, 28-34.

Jönsson, E.G., Flyckt, L., Burgert, E., Crocq, M.-A., Forslund, K., Mattila-Evenden, M., Rylander, G., Åsberg, M., Nimgaonkar, V.L., Edman, G., Bjerkenstedt, L., Wiesel, F.-A., Sedvall, G.C., 2003. Dopamine D3 receptor gene Ser9Gly variant and schizophrenia: association study and metaanalysis. Psychiatric Genetics 13, 1-12.

Kennedy, J.L., Billett, E.A., Macciardi, F.M., Verga, M., Parsons, T.J., Meltzer, H.Y., Lieberman, J., Buchanan, J.A., 1995. Association study of dopamine D3 receptor gene and schizophrenia. American Journal of Medical Genetics 60, $558-562$.
Kremer, I., Rietschel, M., Dobrusin, M., Mujaheed, M., Murad, I., Blanaru, M., Bannoura, I., Muller, D.J., Schulze, T.G., Reshef, A., Gathas, S., Schwab, S., Wildenauer, D., BachnerMelman, R., Belmaker, R.H., Maier, W., Ebstein, R.P., 2000. No association between the dopamine D3 receptor Bal I polymorphism and schizophrenia in a family-based study of a Palestinian Arab population. American Journal of Medical Genetics 96, 778-780.

Lannfelt, L., Sokoloff, P., Martres, M.P., Pilon, C., Giros, B., Jönsson, E., Sedvall, G., Schwartz, J-C., 1992. Amino acid substitution in the dopamine D3 receptor as a useful polymorphism for investigation psychiatric disorders. Psychiatric Genetics 2, 249-256.

Le Coniat, M., Sokoloff, P., Hillion, J., Martres, M.P., Giros, B., Pilon, C., 1991. Chromosomal localization of the human D3 dopamine receptor gene. Human Genetics 87, 618-620.

Li, T., Arranz, M., Aitchison, K.J., Bryant, C., Liu, X., Kerwin, R.W., Murray, R., Sham, P., Collier, D.A., 1998. Casecontrol, haplotype relative risk and transmission disequilibrium analysis of a dopamine D2 receptor functional promoter polymorphism in schizophrenia. Schizophrenia Research 32, 87-92.

Macciardi, F., Verga, M., Kennedy, J.L., Petronis, A., Giuseppe, B., 1994. An association study between schizophrenia and the dopamine receptor genes DRD3 and DRD4 using the haplotype relative risk. Human Heredity 44, 328-336.

Mant, R., Williams, J., Asherson, P., 1994. Relationship between homozygosity at the dopamine D3 receptor gene and schizophrenia. American Journal of Medical Genetics 54, 21-27.

McGuffin, P., Owen, M.J., Farmer, A.E., 1995. The genetic basis of schizophrenia. Lancet 346, 678-682.

Miller, S.A., Dykes, D.D., Polesky, H.F., 1988. A simple salting out procedure for extracting DNA from human nucleated cells. Nucleic Acids Research 16, 1215.

Missale, C., Nash, S.R., Robinson, S.W., Jaber, M., Caron, M.G., 1998. Dopamine receptors: from structure to function. Physiological Reviews 78, 189-225.

Morimoto, K., Miyatake, R., Nakamura, M., Watanabe, T., Hirao, T., Suwaki, H., 2002. Delusional disorder: molecular genetic evidence for dopamine psychosis. Neuropsychopharmacology 26, 794-801.

Nimgaonkar, V.L., Zhang, X.R., Caldwell, J.G., Ganguli, R., Chakravarti, A., 1993. Association study of schizophrenia with dopamine D3 receptor gene polymorphisms: probable effects of family history of schizophrenia? American Journal of Medical Genetics 48, 214-217.

Prasad, S., Deshpande, S.N., Bhatia, T., Wood, J., Nimgaonkar, V.L., Thelma, B.K., 1999. Association study of schizophrenia among Indian families. American Journal of Medical Genetics 88, 298-300.

Rothschild, L.G., Badner, J., Cravchik, A., Gershon, E.S., Gejman, P.V., 1996. No association detected between a D3 receptor gene-expressed variant and schizophrenia. American Journal of Medical Genetics 67, 232-234.

Sasaki, T., Macciardi, F.M., Badri, F., Verga, M., Meltzer, H.Y., Lieberman, J., Howard, A., Bean, G., Joffe, R.T., Hudson, 
C.J., Kennedy, J.L., 1996. No evidence for association of dopamine D2 receptor variant (Ser311/Cys311) with major psychosis. American Journal of Medical Genetics 67, 415-417.

Schindler, K., Torre, C.D., Bauer, A., Medeiros, H., Carvalho, C., Fernandes, L.F., Pato, M.T., Pato, C.N., 1999. Identification of a highly homogenous population for genetic study of psychiatric disorders. CNS Spectrums 4, 22-24.

Shaikh, S., Collier, D.A., Sham, P.C., Ball, D., Aitchison, K., Vallada, H., Smith, I., Gill, M., Kerwin, R.W., 1996. Allelic association between a Ser-9-Gly polymorphism in the dopamine D3 receptor gene and schizophrenia. Human Genetics 97, 714-719.

Sokoloff, P., Giros, B., Martres, M.-P., Bouthenet, M.-L., Schwartz, J.-C., 1990. Molecular cloning and characterization of a novel dopamine receptor (D3) as a target for neuroleptics. Nature 347, 146-151.

Spielman, R.S., Ewens, W.J., 1998. A sibship test for linkage in the presence of association: the sib transmission/disequilibrium test. American Journal of Human Genetics 62, $450-458$.

Spielman, R.S., McGinnis, R.E., Ewens, W.J., 1993. Transmission test for linkage disequilibrium: the insulin gene region and insulin-dependent diabetes mellitus (IDDM). American Journal of Human Genetics 52, 506-516.

Spurlock, G., Williams, J., McGuffin, P., Aschauer, H.N., Lenzinger, E., Fuchs, K., Sieghart, W.C., Meszaros, K., Fathi, N., Laurent, C., Mallet, J., Macciardi, F., Pedrini, S.,
Gill, M., Hawi, Z., Gibson, S., Jazin, E.E., Yang, H.-E., Adolfsson, R., Pato, C.N., Dourado, A.M., Owen, M.J., 1998. European multicentre association study of schizophrenia: a study of the DRD2 Ser 311Cys and DRD3 Ser 9Gly polymorphisms. American Journal of Medical Genetics 81, 24-28.

Tanaka, T., Igarashi, S., Onodera, O., Tanaka, H., Fukushima, N., Takahashi, M., Kameda, K., Tsuji, S., Ihda, S., 1996. Lack of association between dopamine D2 receptor gene Cys311 variant and schizophrenia. American Journal of Medical Genetics 67, 208-211.

Terwilliger, J.D., Ott, J., 1992. A haplotype-based 'Haplotype Relative Risk' approach to detecting allelic associations. Human Heredity 42, 337-346.

Williams, J., Spurlock, G., Holmans, P., Mant, R., Murphy, K., Jones, L., Cardno, A., Asherson, P., Blackwood, D., Muir, W., Meszaros, K., Aschauer, H., Mallet, J., Laurent, C., Pekkarinen, P., Seppala, J., Stefanis, C.N., Papadimitriou, G.N., Macciardi, F., Verga, M., Pato, C., Azevedo, H., Crocq, M.-A., Gurling, H., Kalsi, G., Curtis, D., McGuffin, P., Owen, M.J., 1998. A meta-analysis and transmission disequilibrium study of association between the dopamine D3 receptor gene and schizophrenia. Molecular Psychiatry 3, 141-149.

Yang, L., Li, T., Wiese, C., Lannfelt, L., Sokoloff, P., Xu, C.T., Zeng, Z., Schwartz, C., Liu, X., Moises, H.W., 1993. No association between schizophrenia and homozygosity at the D3 dopamine receptor gene. American Journal of Medical Genetics 48, 83-86. 